\title{
Seni Musik Hadrah Putri di Pondok Pesantren Al Munawwir Krapyak
}

\author{
ANDRE INDRAWAN ${ }^{1}$, SUSANTI ANDARI, DAN SURYATI
}

Jurusan Musik, Fakultas Seni Pertunjukan, Institut Seni Indonesia Yogyakarta

\begin{abstract}
Hadrah Music in Pondok Pesantren Al Munawwir Krapyak. This study investigates an Islamic musical genre known as the Hadrah, practiced by female students of the Pondok Pesantren (Islamic boarding school) Al Munawwir. It is based on an ethnomusicological field research conducted between May 2007 and September 2008.This study finds that basic song form is exist in the Hadrah's songs while their lyrics are mostly taken from classical as well as popular Islamic poem collections. Although the Hadrah song was performed by melodic ornamental improvisation techniques that normally applied in reciting the Qur'an, the singer always try to follow the Arabic reading rules carefully. This finding has given us an indication that in order to achieve a good result of musical production, as well, the Hadrah singers have to master not only the art of Holy Qur'an recitation but also Arabic language fluency. The female Hadrah is normally performed as a religious entertainment in the school's traditions, such as anniversary and graduation celebrations.
\end{abstract}

Key words: Islamic music, hadrah, ethnomusicology

\section{Pendahuluan}

Pada kebanyakan masyarakat Islam, penampilan musik di depan umum oleh kaum wanita, sekalipun membawakan repertoar relijius, dianggap tabu. Suara, dan bahkan seluruh bagian tubuh wanita, kecuali wajah, adalah aurat dan oleh karenanya haram untuk diperdengarkan dan dipertontonkan. Di samping itu, terdapatnya keyakinan di masyarakat bahwa status musik dalam hukum Islam adalah haram, telah memperkuat kondisi tersebut (Al Kanadi, 1991). Walaupun demikian terdapat kenyataan yang tidak dapat dipungkiri bahwa dalam dunia Islam juga terdapat tradisitradisi musikal, baik yang dipraktekan dalam kegiatan-kegiatan ritual maupun sosial. Kenyataan lain juga menunjukkan bahwa keterlibatan wanita dalam beberapa tradisi pertunjukan seni relijius Islamis, seperti misalnya dalam seni Hadrah yang banyak menggunakan repertoar Kasidah, bukanlah merupakan masalah yang besar. Walaupun Hadrah biasanya dinyanyikan oleh lakilaki dengan iringan seperangkat rebana, namun kadang-kadang juga dilakukan oleh kelompok perempuan, sebagaimana yang dilakukan di beberapa pedesaan Islam dan Pondok Pesantren
(PP) di Daerah Istimewa Yogyakarta (DIY). Studi ini dilakukan melalui observasi lapangan terhadap kegiatan Hadrah yang dilaksanakan di pemondokan santri putri Kompleks Q, Pondok Pesantren Al-Munawwir, Krapyak, Bantul, DIY.

\section{Musik Hadrah}

Etnomusikologi adalah kesatuan dari dua pendekatan berbeda, yaitu musikologis dan etnologis yang tidak menekankan salah satu di antara keduanya (Merriam 1964: 3,17). Sehubungan dengan itu Merriam (1964) mendefinisikan etnomusikologi sebagai studi musik dalam kebudayaan. Etnomusikologi berbagi dengan disiplin-disiplin lain baik dalam hal pandangan dasar maupun metode-metode sehingga tidak jauh berbeda dari bidang-bidang lain namun kemudian dimodifikasi sesuai dengan penekanan yang dipilih. Sehubungan dengan itu metode dan data yang berada dalam lingkup disiplin atau sumber-sumber lain, sebagaimana disarankan List (1979), dapat juga digunakan selama masih dapat membantu dalam pemahaman pola-pola musikal yang wajar (lihat Supanggah, ed., 1995: 3738). Laporan etnomusikologis ini adalah sebuah

1 Alamat korespondensi: Prodi Musik ISI Yogyakarta, Jln. Parangtritis Km. 6,5 Sewon, Yogyakarta, Tlp. 0274-375380, e-mail: indrawan_andre@yahoo.com 
etnografi musik yang didasarkan atas peristiwaperistiwa musikal (Seeger 1995, 88). Sehubungan dengan itu sampel dipusatkan pada produksi musik yang meliputi tidak saja para penyaji Hadrah tapi juga pada komunitas pendukungnya. Dengan demikian disamping analisis musikologis, analisis kualitatif terhadap data-data non musikal juga dilibatkan.

Analisis musikologis dilakukan terhadap transkripsi dari rekaman data-data lapangan. Beberapa lagu hasil transkripsi dipilih untuk dikaji dengan pendekatan analitikal, yaitu dengan cara memecah struktur musikal ke dalam bagian-bagian yang lebih kecil guna memahami bagaimana elemenelemen tersebut tersusun sehingga memiliki kesesuaian dalam membentuk keseluruhan struktur (Merriam 1964, 300 jo Watanabe, 1967: 5). Sementara itu analisis kualitatif dilakukan terhadap hasil wawancara dengan Kyai pengasuh, beberapa orang pengurus kompleks $Q$ dan para peserta Hadrah. Analisis antropologis diterapkan dalam rangka memperoleh informasi mengenai tradisi Hadrah di pesantren tersebut (Titon 2003, 171-180).

Setelah melakukan survei pendahuluan ke Kompleks Q, secara resmi penelitian lapangan dimulai dengan melakukan kunjungan langsung ke Kantor Pusat. Dari para pengurus kantor tersebutlah penjelasan selengkapnya tentang kegiatan-kegiatan kesenian, termasuk Hadrah oleh para santri putri diperoleh. Di samping itu mereka juga menjelaskan struktur organisasi PP Al Munawwir secara panjang lebar. Pengurus menyarankan agar pengamatan khusus terhadap Hadrah dilakukan langsung ke Kompleks Q.

Lokasi PP Al-Munawir, yang terletak di dusun Krapyak, Desa Panggungharjo, Kecamatan Sewon, Kabupaten Bantul, Daerah Istimewa Yogyakarta (DIY), dipilihsebagai tempat penelitian karena sampelnya memiliki kelayakan untuk diteliti. Sebenarnya lokasi ini terbentang di antara dua wilayah berbeda yaitu Kotamadya Yogyakarta dan Kabupaten Bantul, atau dengan kata lain berada di perbatasan keduanya. Pesantren ini didirikan pertama kali oleh KH Moehammad Moenauwir pada tahun 1910, yang wafat pada tahun 1942 dan dimakamkan di sekitar pesantren tersebut. ${ }^{4}$ Pesantren yang menerapkan metode pendidikan tradisional Islamis ini berbasis keagamaan Nadhatul Ulama. Dari sejumlah 124 pesantren yang terdaftar pada Departemen Agama Republik Indonesia DIY hingga 2001 (lihat database Depag 2002) jumlah pesantren NU adalah yang terbesar, dan PP Al-Munawir adalah salah satu di antaranya yang paling tua dan terkenal dalam skala nasional. Sebagai sampel, pengambilan data dibatasi pada kegiatan Hadrah putri di pemukiman Kompleks Q.

Semula pesantren ini disebut Pesantren Krapyak. Penambahan nama pendirinya, sehingga secara lengkap disebut PP Al-Munawwir Krapyak Yogyakarta, dilakukan pada sekitar tahun 1976. Sesuai dengan spesialisasi pendirinya sebagai figur ahli Al-Qur'an, maka kini pesantren inipun memiliki spesialisasi dalam bidang AlQur'an. Walaupun demikian pembahasan studi keagamaan yang dikembangkan juga meliputi ilmu-ilmu Islam lainnya, khususnya yang bersumber dari Kitab Kuning, yang di antaranya diterapkan dengan sistem sorogan (pendekatan hapalan individual). Sekarang metode tersebut dikombinasikan dengan sistem madrasah (klasikal) yang kemudian menumbuhkan beberapa lembaga pengelola pendidikan.

Dalam menjalani proses pendidikan, parasantri diwajibkan untuk mengikuti pengajian Al-Qur'an dan juga untuk ikut salat berjamaah bersama Kyai setiap hari. Di samping itu mereka juga diwajibkan berziarah ke makam leluhur setiap Kamis sore. Bagi santri pria dianjurkan memakai sarung, kemeja, dan kopyah putih. Mereka dilarang nonton film, keluar pondok tanpa ada kepentingan, bertamasya kecuali pada waktu tertentu, keluar pada malam hari, dan memegang Al-Qur'an dalam keadaan tidak suci. Bagi yang melanggar maka hukumanhukumannya ialah telapak kaki dipukul dengan rotan, direndam dalam kolam, diwajibkan membaca selawat narriyah saat berrendam, lutut dan pusar dipukul jika terlihat, denda ringan, diakhirkan giliran mengajinya, dan yang paling keras ialah dikeluarkan dari pondok.

Hingga kini PP Al-Munawwir telah memasuki periode kepemimpinan yang keempat. Periode pertama di bawah kepemimpinan KH M. Moenauwir berlangsung dari tahun 1910 hingga 1942. Setelah itu PP ini dipimpin oleh tiga Kyai yaitu KH A. Affandi, KH. R. Abdul Qodir, dan KH Ali Masum, dari tahun 1942 hingga 1968. Pada periode ketiga, yaitu dari tahun 1968 hingga 1989, PP Al Munawwir Krapyak dipimpin oleh KH Ali 
Maksum, dan untuk periode kepengurusaan saat ini sejak tahun 1989 hingga kini dipimpin oleh KH Zainal Abidin Munawwir.Saat ini unit kerja PP Al-Munawwir meliputi bidang-bidang (1) Pendidikan dan Pengajaran yang meliputi aspekaspek pendidikan kepesantrenan, ketrampilan, perpustakaan, penerbitan, dan penelitian ilmiah; (2) Kesantrian yang meliputi administrasi, asrama, surat/ wesel, ketertiban dan keamanan, bimbingan dan penyuluhan, dan pengembangan bakat dan minat; (3) Humas dan Pengembangan Masyarakat, yang meliputi dakwah, bakti sosial, koperasi, pelatihan kesehatan, dan peningkatan ekonomi masyarakat; dan (4) Sarana-prasarana yang meliputi perencanaan, kerumahtanggaan, pemeliharaan serta kebersihan lingkungan, dan listrik.

Struktur organisasi pesantren terdiri dari Ahlul Bait, Majlis Pengasuh, dan Dewan Pengurus. Ahlul Bait terdiri dari anak keturunan $\mathrm{KH} \mathrm{M}$. Moenauwir. Majlis Pengasuh terdiri dari lima orang yaitu $\mathrm{KH}$ Zainal Abidin Munawwir (PP Al Munawwir), KH Dalhar Munawwir (Pondok Nurussalam), KH Ahmad Warsun Munawwir (Kompleks Q), KH Ahmad Munawwir (Kompleks L), dan KH RM Najib A. Q. (Kompleks H). Badan kepengurusan dipimpin oleh $\mathrm{KH}$ Ahmad Warsun Munawwir sebagai mandataris, dengan susunan kepengurusan yang terdiri dari seksiseksi pendidikan dan pengajaran, kesantrian, humas serta pengabdian masyarakat, dan saranaprasarana. Di bawah badan pengurus ialah para pengurus kompleks, dan barulah para santri pada lapisan terbawah. Lembaga-lembaga pendidikan yang berada di bawah naungan PP Al-Munawwir Krapyak saat ini di antaranya ialah Madrasah Huffadz, Madrasah Salafiyah I-IV, Al-Ma'had Al-Aly (Perguruan Tinggi Ilmu Salaf), Majlis Ta’lim, dan Majlis Masyayih. Secara umum sistem pendidikan di PP Al-Munawwir berciri salafi yang para pengajarnya terdiri dari para Kyai, Ustadz dan santri-santri senior. Selain warga DIY, santriantri di pondok pesantren ini juga datang dari luar negeri yang di antaranya dari Korea, Malaysia, dan Thailand. Kegiatan santri mulai dari dini hingga malam hari.

Pemukiman santri terdiri dari 18 kompleks yaitu dari A hingga R. Pengurus kompleks dibantu oleh pengurus harian yang membidangi Ibadah, kejamaa'han, pendidikan, kebersihan, ketertiban dan keamanan, olah raga dan kesehatan, pengkaderan, penerangan, perpustakaan, keputrian. Kompleks dibagi berdasarkan tingkat atau jenis pendidikan. Penelitian ini dilakukan di Pondok $\mathrm{Q}$, yang dikenal sebagai pondok santri putri. Menurut wawancara dengan santri pengurus pusat PP Al Munawwir, di samping Pondok Q, pondok khusus putri yang lainnya ialah Pondok R. Sementara Pondok Q ditempati oleh para Santri Pelajar Putri, Pondok R oleh Santri Salafiah putri.

Sebagian besar santri di pondok $Q$ ialah mereka yang bersekolah hingga kuliah di sekolah atau perguruan tinggi umum namun menginap di pondok dan mengikuti semua kegiatan yang diselenggarakan oleh pondok. Santri PP AlMunawwir dikategorikan kepada lima jenis, yaitu: (1) Santri Salafiah, yang khusus mendalami agama Islam pada semua tingkat Salafiyah, dari I hingga IV; (2) Santri Huffadz, yang menghapalkan AlQur'an, bagi yang khusus menjalani studi di pondok maupun yang tidak; (3) Santri Pelajar yang bersekolah di sekolah umum; (4) Santri Ma'had Aly, yaitu yang mengikuti pendidikan tinggi di Perguruan Tinggi Ma'had Aly Al-Munawwir (Perguruan Tinggi Ilmu Salaf); dan (5) Santri Kalong, yaitu yang mengikuti kegiatan pesantren namun bertempat tinggal di luar pesantren.

\section{Analisis Musikologis Hadrah Putri}

Analisis musikologis meliputi sumber-sumber repertoar, transkripsi sampel lagu, analisis bentuk musik, dan ciri khas Hadrah. Sumber repertoar dari lagu-lagu yang dibawakan oleh kelompok Hadrah putri Kompleks Q umumnya diambil dari syair-syair Al Barzanji yang berisi pujianpujian atas Nabi Muhammad SAW. Namun demikian saat penelitian ini dilakukan syair lagu yang sedang mereka latih berjudul "Rohmaka," diambil dari sebuah buku berjudul Kumpulan Qasidah Islamiyah yang disusun oleh Misbahu Munir (2004). Buku tersebut berisi kumpulan 500 syair Arab Islamis dari berbagai negara, seperti Siria, Andalus, Hadramaut, dan juga Indonesia, yang berisi nasihat-nasihat agama, puji-pujian, doa munajat, dan selawat.

Guna memahami aspek-aspek musikologis dari lagu Hadrah, rekaman lapangan permainan lagu Rohmaka ditranskrip dengan tulisan tangan ke dalam notasi balok. Karena lagu yang dinyanyikan 
berbahasa Arab, apalagi dengan kualitas hasil rekaman yang tidak standar, lirik lagu tidak dapat dideteksi dengan mudah. Teks yang terdapat dalam buku juga tidak banyak membantu karena tertulis dalam huruf Arab. Beruntung teks Arab tersebut telah disesuaikan dengan audiens Indonesia sehingga sudah menggunakan tanda-tanda vokal (harokat) yang memudahkan pembuatan transliterasi, seperti tertulis dalam teks berikut:

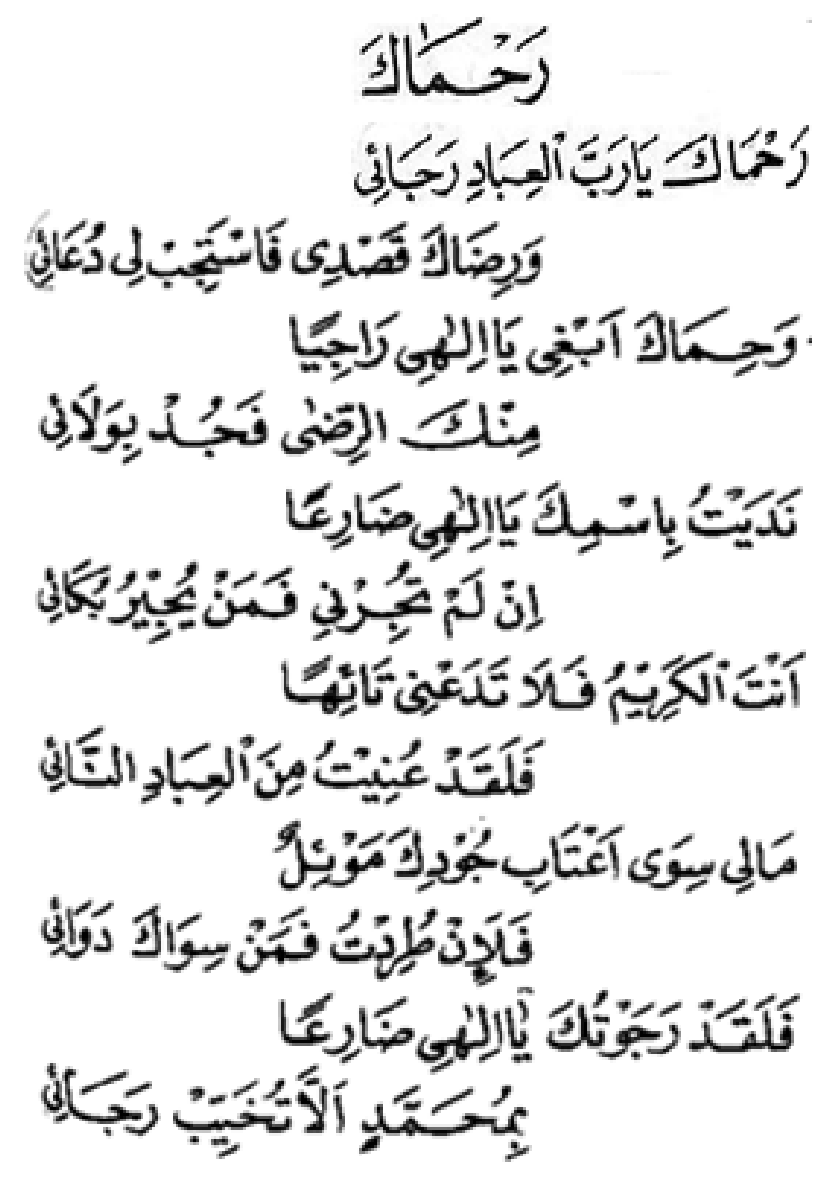

Walaupun syair Rahmaka terdiri dari 12 baris namun kelompok Hadrah putri Kompleks Q hanya membawakan enam baris pertama saja. Penulisan transliterasi dari huruf Arab ke huruf Latin bukanlah hal yang mudah karena diperlukan kompetensi khusus dalam membaca tulisan Arab. Pada transliterasi lagu Rohmaka di bawah ini, kata Rajâ-i, yaitu kata terakhir dari baris pertama, diulang sebagai gaung (echo). Dalam teks Arab, kata tersebut hanya tertulis satu kali dan selanjutnya pada setiap baris, kata terakhir selalu diulang sebagaimana pada baris pertama.

\begin{tabular}{|c|c|c|}
\hline BARIS & TEKS & ENGULANGAI \\
\hline 1 & Rahmâka yâ rabbal 'ibâdi rajâ-i, rajâ-i & ) \\
\hline 2 & Wa ridhâka khashdâ fâstajibli du'â-i, $d u$ 'â-i & $-i$ \\
\hline 3 & Wa himâka abghi yâ ilahî râjizya, râjiya & $\mathbf{2}$ \\
\hline 4 & Mankarridhâ Fajud bi wala-i, bi wala-i & 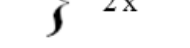 \\
\hline 5 & Nadaitubismika yâ ilahî dhâri'ah. Dhâri'ah & $h$ \\
\hline 6 & Inlam tujirni famayyujiirubukâ-i, bukâ-i & $\boldsymbol{5}$ \\
\hline
\end{tabular}

Keenam baris berikutnya dapat dilagukan sama seperti pada enam baris pertama. Walaupun demikian melodi Hadrah tidak pernah persis sama pada ulangannya, karena tampaknya: (1) Penekanan musik Hadrah tidak pada musiknya melainkan syairnya, (2) musik Hadrah yang bersifat spontanitas dan improvisatoris ini diturunkan melalui tradisi oral atau tidak tercatat.

Dalam transkrip notasi standar tampak bahwa kedua frase kalimat melodi terdiri dari sebuah semi frase dua birama dan sebuah semi frase satu birama. Secara teori biasanya frase kalimat musik terdiri dari dua semi frase yang masing-masing terdiri dari paling tidak dua birama. Pada lagu ini setiap baris terdiri dari kombinasi: (1) dua birama, dan (2) satu birama penutup yang merupakan pengulangan kata terakhir sebagai echo. Setiap dua baris membentuk satu kalimat dengan frase tanya pada baris pertama kemudian frase jawab pada baris kedua.

Perubahan-perubahan pada kesatuan motifik yang terjadi sebagaimana terlihat pada transkripsi tersebut, yaitu setiap dua baris, menunjukkan bahwa melodi tersebut memiliki tiga motif yang khas. Dengan demikian baris pertama dan kedua dapat disebut sebagai kelompok A, baris ketiga dan keempat sebagai kelompok B, dan baris kelima dan keenam sebagai kelompok C. Kekhasan tersebut terlihat dari perbedaan yang signifikan di antara masing-masing ketiga kelompok dua baris tersebut. Pengulangan masing-masing "kelompok dua baris" dengan sendirinya membentuk satu periode kembar yang terdiri dari dua pasang kalimat yang masing-masing terdiri dari frase berbirama tiga. 


\section{ROHMAKA}

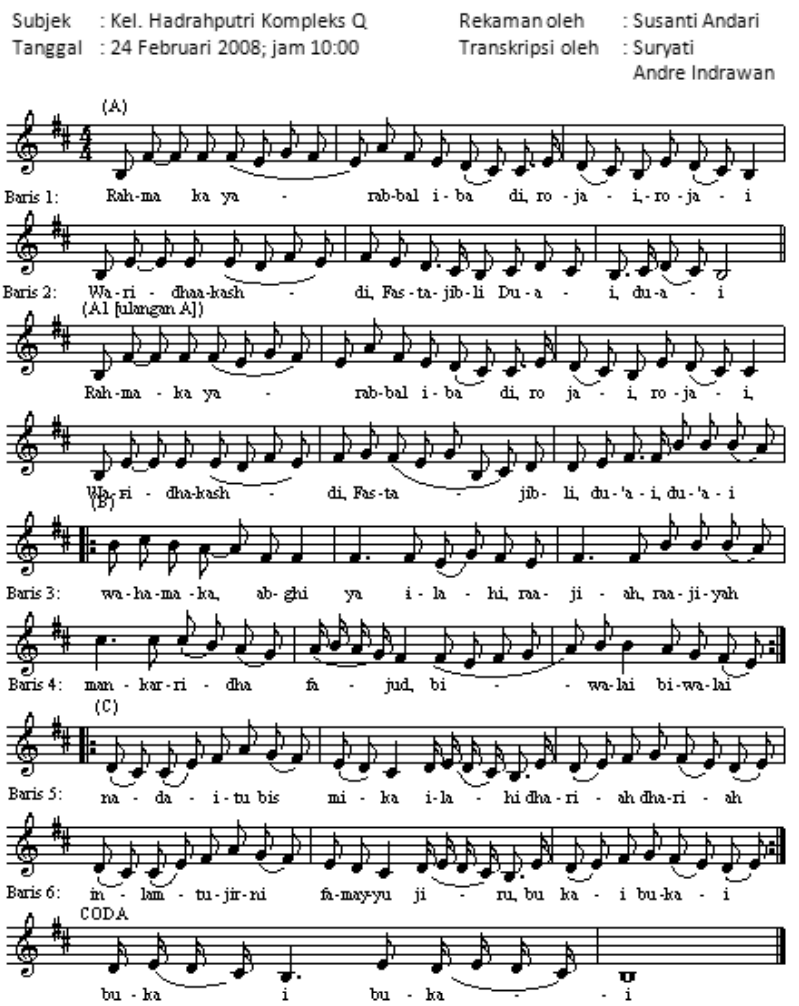

Notasi 1. Transkripsi lagu Rohmaka

Walaupun demikian melodi tersebut tidak dapat dikatakan sebagai "bentuk lagu tiga bagian" karena kelompok ketiga berbeda dari dua kelompok sebelumnya. Pada bentuk lagu tiga bagian biasanya kelompok ketiga adalah ulangan dari kelompok pertama (Lihat Stein, 1961: 69-74, dan Prier, 1996:12-14).

Variasi iringan Hadrah dapat dikelompokkan ke dalam tiga macam pola ritmis yang berbeda dan digunakan pada saat-saat tertentu dalam penyajian lagu. Menurut catatan lapangan, sebagai hasil wawancara yang dilakukan oleh salah seorang anggota tim peneliti, bentuk penyajian lagu Hadrah bersifat fleksibel: "Bisa diawali dengan vokal atau musik, tetapi pada umumnya pada kelompok tersebut lebih banyak menggunakan vokal dulu sepanjang satu baris kemudian disusul dengan musik." Dalam catatannya yang lain disebutkan: "Dalam penyajiannya pada umumnya didahului dengan solo vokal kemudian disusul iringan yang lembut (turun) setelah beberapa bait (ayat) dilanjutkan koor dengan iringan yang keras (naik)." Dari catatan tersebut terdapat hal yang unik bahwa para musisi Hadrah ternyata memiliki istilah-istilah yang khas untuk menyebut aspek-aspek musikal tertentu, seperti "turun” dan "naik."

Ketiga pola ritmis tersebut ialah Golong, Genjring, dan Tikah. Berdasarkan produksi suaranya, transkripsi ritmis pengiring dilam bangkan dengan huruf T untuk bunyi "tak" dan D untuk bunyi "dung". Setiap jenis irama dasar, yaitu, Golong, Genjring, dan Tikah, memiliki struktur fungsional yang sama yaitu: (1) pola iringan untuk solo vokal dalam dinamika "turun", (2) iringan koor dengan dinamik "naik", dan (3) iringan variasi untuk koor. Pola pukulan Golong ialah sebagai mana tampak pada catatan lapangan berikut ini:

Slawatan putri atau Hadroh mempunyai 3 macam pola ritme musik untuk mengiringi suatu lagu yaitu Golong, Gerinjing dan Tikah. Pola ritme tersebut ditulis dengan lambarig $T$ (Tak) dan $D$ (Dung). Dalam penyajiannya pada umumnya didahului dengan solo koor dengan iringan yang keras (naik.

1. GOLONG - Ritme dasor

$T, \widetilde{D D}, T, D \rightarrow$ iringan solo vokal dengan diulang-ulang dinamik lembut

$D \cdot \bar{\pi}, T, \gamma \rightarrow 2 \mathrm{X}$ iringan untuk koor dinamik keras

D. D. D. D

T , TD . T . T

T . TD . T . D

T , T , T , T

$\overline{\mathrm{TD}} \cdot T \cdot \mathrm{D}, \mathrm{T} \rightarrow$ iringan variasi untuk koor diulang-ulang

T. $\overline{\mathrm{TD}} \cdot \mathrm{T} \cdot \mathrm{D}$

Apabila ditulis dalam notasi balok

1. GOLONG

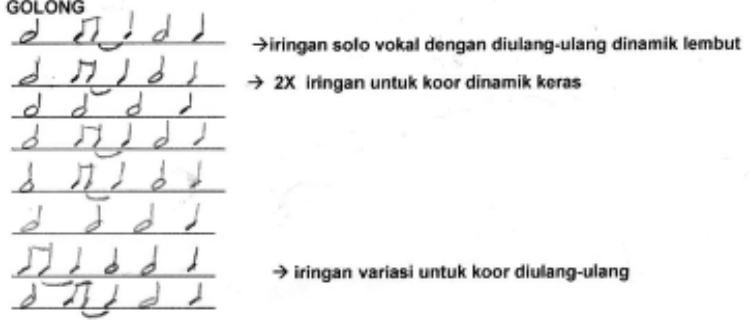

Notasi 2. Catatan lapangan notasi tradisional irama Golong.

Irama dasar Golong dimulai dengan satu pola ritmis kemudian disusul dengan variasi dari dua macam pola dan ditutup dengan pengulangan sederhana dari dua pola berbeda yaitu:
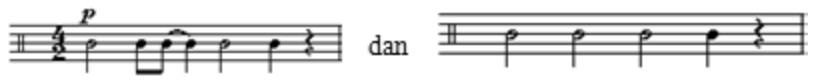

Notasi 3. Pola dasar Golong

Sebagaimana Golong, pola pukulan Genjring dan Tikah juga diterapkan pada tiga bagian internal, yaitu: (1) iringan untuk solo vokal yang diulang-ulang dengan dinamika "turun," (2) pola iringan yang dimainkan dua kali untuk koor 
dengan dinamika "naik" dan (3) iringan variasi untuk vokal yang diulang-ulang. Pembagian variasi pola tersebut adalah sebagaimana tampak pada catatan lapangan sebagai berikut:

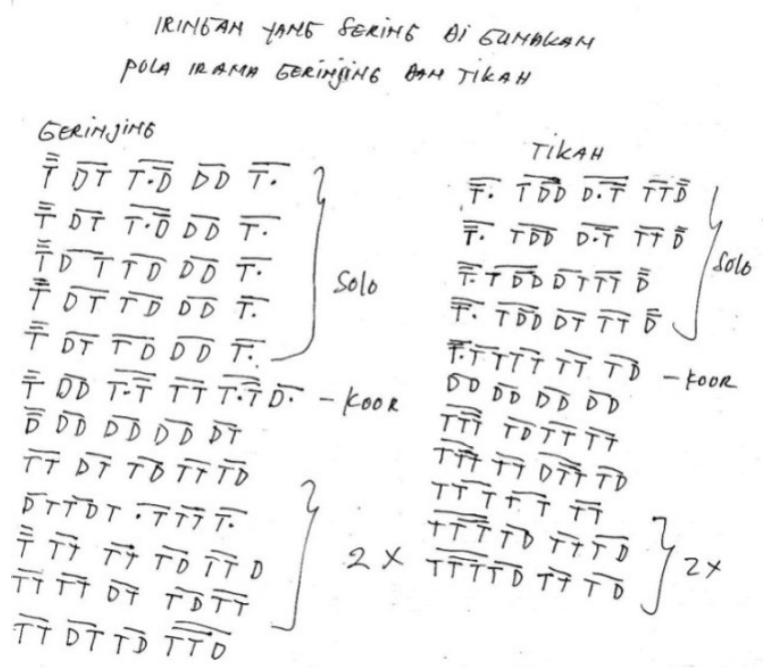

Notasi 4. Catatan lapangan notasi tradisional irama Genjring dan Tikah.

Sebagaimana halnya yang terdapat pada ke lompok ritmis pengiring Golong, masing-masing dari pola kelompok ritmis Genjring dan Tikah memiliki dua jenis pola dasar yang berbeda, sementara yang lainnya merupakan ulangan atau modifikasi dari keduanya. Pada Genjring pola dasar tersebut ialah:
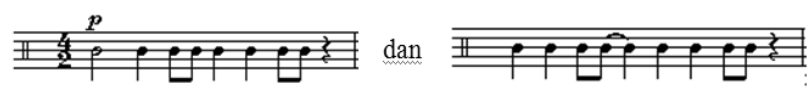

Notasi 5. Pola dasar Genjring

Sementara itu kedua pola yang mendasari kelompok ritmis Tikah ialah sebagai berikut:
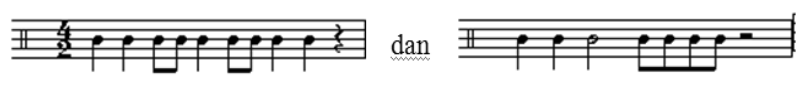

Notasi 6. Pola dasar Tikah

Dari transkripsi ritmis di atas dapat kita maklumi bahwa walaupun menurut para analis, ketiga kelompok pola iringan tersebut didasari oleh pola irama yang berada dalam 7 ketukan per birama, namun dalam kenyataannya menurut rekaman lapangan ialah genap 4 ketukan per birama. Kesimpulan transkripsi tersebut dapat dimaklumi karena diturunkan dari catatan lapangan bukan dari rekaman suara. Hingga tahap laporan penelitian ini ditulis belum dikaji lebih jauh apakah irama 8/4 tersebut berarti dua birama dari irama $4 / 4$ yang masing-masing biramanya memiliki srtruktur ritmis berbeda yang merupakan kesatuan pola dasar? Ataukah satu birama empat ketukan dari irama 4/2? Berikut ialah transkripsi dari notasi tradisional ke notasi ritmis:

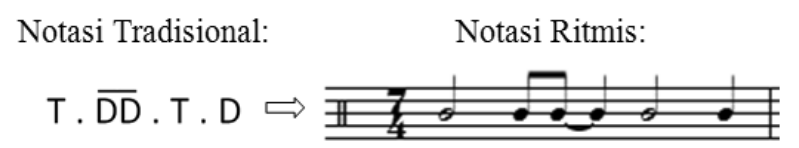

Notasi 7. Notasi tradisional pola dasar Golong dan hasil transkripsinya

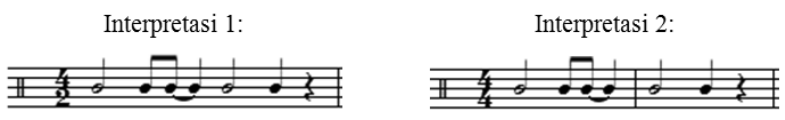

Notasi 8. Interpretasi irama dasar Golong.

Berkaitan dengan hal tersebut dapat disimak kembali pada transkripsi lagu "Rohmaka" (gambar 3) yang iramanya genap 4 ketukan per birama sehingga tidak mungkin pola iringan tersebut diterapkan pada penyajian Hadrah. Agar memiliki kesesuaian dengan transkripsi melodis, maka perlu ditambahkan tanda istirahat satu ketukan setelah ketukan ketujuh sehingga jumlahnya genap menjadi delapan ketukan atau irama 8/4 (lihat interpretasi 2 pada gambar 10).

Jika pola $4 / 2$ tersebut disesuaikan dan diterapkan pada transkripsi melodis maka pola irama dasar tersebut harus memiliki irama yang sama yaitu 4/4. Untuk menyesuaikannya maka transkripsi pola-pola dasar berirama $4 / 2$ tersebut tidak dapat diasumsikan sebagai dua kali (birama) 4/4 namun sebagai satu birama, namun nilai-nilai nadanya perlu dipadatkan menjadi satu birama dalam 4/4. Dengan penyesuaian tersebut maka susunan irama dasar Golong yang diulang-ulang adalah sebagai berikut: 
Interpretasi 3:

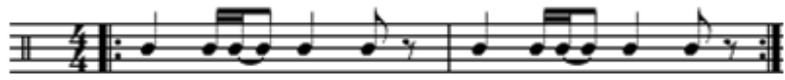

Notasi 9. Interpretasi ketiga yang paling beralasan dari pola irama Golong.

Diskusi interpretasi ritmis di atas hanya eksis dalam analisis. Dalam kenyataannya ketiga kelompok rimis tersebut selalu terdengar wajar dan diterapkan secara fleksibel sehingga kehadiran pola-pola tersebut tergantung dari lagu yang terjadi sebagai respon dari kondisi syair yang digunakan. Dengan kata lain permainan rebana dalam seni Hadrah ini bersifat improvisatoris dan transmisi ketrampilannyapun tidak dengan budaya tertulis atau literal melainkan langsung, atau secara tradisi oral.

\section{Kedudukan Hadrah dalam Tradisi Pesantren}

Pada mulanya Hadrah di PP Al Munawwir hanya dibawakan oleh para santri pria saja. Pada tahap perkembangan berikutnya dimainkan bersama, yaitu santri pria hanya memainkan iringan dengan seperangkat terbang sementara para santri putrinya menyanyi. Formasi ini hingga kini masih dilakukan khususnya dalam acara Haul yang di antaranya juga meliputi kegiatan Wisuda. ${ }^{6}$ Karena putra dan putri berada dalam kompleks terpisah maka akhirnya masing-maing memiliki kelompok Hadrah sediri-sendiri. Kelompok Hadrah putri di Kompleks Q, hingga kini telah berdiri selama lima generasi dua tahunan. Pada kesempatankesempatan tertentu, misalnya peringatan Maulid Nabi, kelompok-kelompok dalam komplekskompleks tersebut kadang-kadang diperlombakan.

Latihan kegiatan-kegiatan kesenian di Kompleks Q umumnya hanya dilakukan menjelang perayaan-perayaan tertentu misalnya peringatan Haul (hari kelahiran sesepuh), Maulid, Wisuda, dsb. Hadrah putri adalah salah satu seni tradisi yang berkembang di lingkungan PP Al Munawir. Seni tersebut pada awalnya dipentaskan dalam acara-acara ritual hari-hari besar Islam, dan juga tradisi dzikiran, syukuran, kataman, dan kelahiran, namun kemudian berkembang menjadi pertunjukan untuk hiburan pernikahan, sunatan, wisuda pondok,dsb.

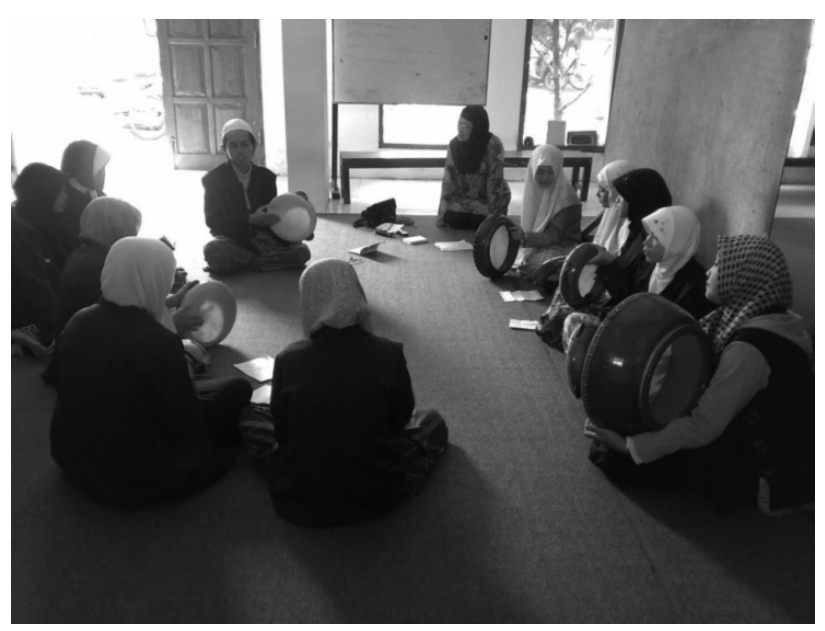

Gambar 1. Latihan Hadrah putri dengan 8 pemain terbang dan 3 penyanyi. (Foto: Susanti Andari).

Dengan demikian kesenian Hadrah umumnya dibawakan pada perayaan-perayaan penting seperti memperingati kelahiran Nabi, pendiri pondok pesantren, dan hari-hari besar Islam. Satu kelompok Hadrahterdiri dari 7 hingga 10 orang perkusionis dan 2 hingga 4 penyanyi. Instrumen yang mereka gunakan terdiri dari 8 terbang berukuran sedang dan sebuah bas terbang yang biasa juga disebut jidor. Seperangkat instrumen pengiring tersebut dimainkan dengan dua irama dasar yang disebut gerinjing dan Tikah.

Dalam acara-acara resmi mereka berHadrah dengan memakai pakaian yang seragam. Jumlah pemain berkisar dari lima sampai 15 orang. Dalam latihan biasanya didatangkan pelatih dari para seniornya. Latihan-latihan secara intensif dilakukan menjelang perlombaan atau perayaan hari-hari besar. Dalam latihan, baik para santri maupun pelatih duduk bersama di lantai dengan membentuk formasi lingkaran. Sebelum mengajarkan lagu-lagu Hadrah terlebih dahulu pelatih mengajarkan irama-irama dasar. Proses pembelajaran dilakukan dengan memberi contoh terlebih dahulu kemudian diikuti oleh peserta. Demikian hal tersbut dilakukan secara berulangulang hingga permainan iringan cukup lancar. Setelah itu barulah diajarkan lagu-lagu Hadrah.

Pertunjukan Hadrah yang sudah rutin, paling tidak setiap tahunnya ialah dalam rangka memeriahkan Wisuda bagi para Santri putri pondok Q, yang mengikuti studi di SMK PP Al Munawwir. Walaupun para santri putri di Kompleks Q adalah santri pelajar namun sebagian dari mereka belajar di SMK yang dikelola oleh 


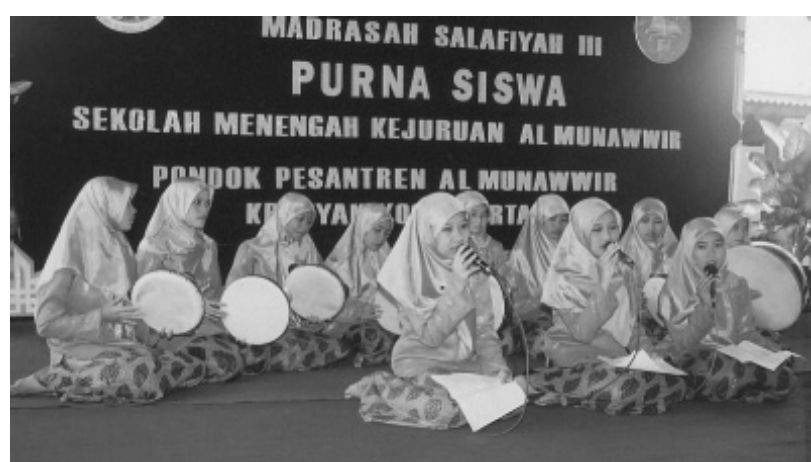

Gambar 2. PertunjukanHadrah dalam acara wisuda pesantren (Foto: Koleksi pengurus Kompleks Q; digunakan dengan ijin).

pondok pesantren. Pendidikan SMK para santri Pondok Q tergolong ke dalam jenis pendidikan Madrasah Salafiyah III. Sebagaimana yang telah dilakukan dalam latihan-latihan, penampilan yang sesungguhnya, pada acara wisuda, juga dilakukan sambil duduk di lantai panggung.

Ketika repertoar yang digunakan pada seni Hadrah bersumber dari syair-syair mawlid, yaitu karya-karya teks klasik berisi riwayat Nabi yang tersusun dari prosa sanjungan, maka penampilan Hadrah tampaknya mirip dengan selawatan. Dengan penyelenggaraannya yang rutin selawatan yang memiliki fungsi sosial keagamaan yaitu sebagai acara silaturahmi. Masyarakat sub kultur pesantren mensikapi kegiatan selawatan sebagai suatu tradisi sakral yang dilakukan oleh beberapa tingkatan kelompok usia dan jender. Kedudukan kegiatan tersebut kira-kira seperti tradisi Yasinan yang biasa dilakukan kelompok pria dewasa dan merupakan ritual pasca kematian. Hadrah, dalam hal ini tidak pernah dilakukan sebagai bagian dari hajatan-hajataninsidental. Perbedaannya ialah jika selawatan memiliki dimensi yang sakral maka Hadrah cenderung sebagai hiburan relijius.

\section{Penutup}

Bentuk musikal lagu Hadrah yang dipraktekan di kompleks Q mengikuti kecenderungan aksentuasi bahasa Arab yang kuat. Kalimat lagu terbentuk dari dua baris syair yang masingmasing syairnya membentuk 3 birama frase pendek. Tampaknya tidak ada suatu melodi yang baku dalam menyanyikan syair-syair Hadrah sehingga semuanya terjadi secara spontan. Lagulagu tersebut dapat diterapkan pada syair-syair yang lain secara fleksibel. Dengan demikian tampaknya kepentingan melodi dikalahkan oleh syair sehingga melodi harus menyesuaikan diri. Dengan demikian untuk dapat menyanyikan lagu Hadrah seseorang tidak hanya trampil membaca tulisan Arab, tapi lebih jauh lagi ialah penguasaan tata bahasa dan budaya Arab.

Berbeda dengan selawatan yang tradisinya dipraktekan mingguan, kegiatan Hadrah yang dipraktekan di PP Al Munawwir tampaknya cenderung diperlakukan sebagai latihan untuk persiapan acara-acara keagamaan yang putaran waktunya lebih lama seperti Haul dan Wisuda. Walaupun demikian dalam acara-acara resmi pesantren, Hadrah tampaknya memiliki peranan yang sangat penting dalam merepresentasikan ciri khas kultur pesantren. Dalam acara-acara tersebut lagu-lagu Hadrah dinyanyikan diselasela acara penting sehingga memiliki makna yang mendalam.

\section{Catatan:}

${ }^{6}$ Transliterasi Huruf Arab :

\begin{tabular}{|c|c|c|c|c|c|}
\hline ARAB & NAMA & TRANS & ARAB & NAMA & TRANS \\
\hline i & $\begin{array}{c}\text { alif/ } \\
\text { hamza }\end{array}$ & $a^{/}$ & ض & dhad & $\mathrm{dh}$ \\
\hline ب ب & $\mathrm{ba}^{\prime}$ & $\mathrm{b}$ & b & tha & th \\
\hline 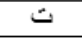 & $\mathrm{ta}^{\prime}$ & $\mathrm{t}$ & ط & zha' & $\mathrm{zh}$ \\
\hline 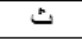 & tsa & ts & $\varepsilon$ & 'ayn & $=$ \\
\hline ج & $\mathrm{jim}$ & $\mathrm{j}$ & $\dot{\varepsilon}$ & ghayn & gh \\
\hline$\tau$ & $\underline{\underline{h}} \mathrm{a}^{\prime}$ & $\underline{h}$ & ف & $\mathrm{fa}^{\prime}$ & $f$ \\
\hline$\dot{\tau}$ & kha' & $\mathrm{kh}$ & قُ & qaf & $\mathrm{q}$ \\
\hline 2 & dal & $\mathrm{d}$ & ] & kaf & $\mathrm{k}$ \\
\hline$j$ & dzal & $\mathrm{dz}$ & J & lam & 1 \\
\hline$J$ & $\mathrm{ra}^{\prime}$ & $\mathrm{r}$ & 5 & $\operatorname{mim}$ & $\mathrm{m}$ \\
\hline j & zay & $z$ & ن & nun & $\mathrm{n}$ \\
\hline س & $\sin$ & $\mathrm{s}$ & 0 & ha' & $\mathrm{h}$ \\
\hline ش & syin & sy & 9 & waw & $\mathrm{w}$ \\
\hline ص & shad & sh & ئي & ya' & $\mathrm{y}$ \\
\hline
\end{tabular}

${ }^{7}$ Simbol huruf untuk dibaca panjang:

\begin{tabular}{|c|c|c|c|c|c|}
\hline \multirow{2}{*}{ No. } & \multirow{2}{*}{ Pemanjangan } & \multirow{2}{*}{ Arab } & \multirow{2}{*}{ Transliterasi } & \multicolumn{2}{|c|}{ Penggunaan } \\
\hline & & & & Kata Arab & Transliterasi \\
\hline 1. & a & L..... & â & 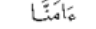 & âmannâ \\
\hline 2. & $\mathrm{i}$ & ل..- لي & $\hat{\mathbf{i}}$ & وَأَنِْى & wallati \\
\hline 3. & u & $9 . .$. & $\hat{\mathrm{u}}$ & 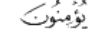 & Yu'minûna \\
\hline
\end{tabular}

\section{Kepustakaan}

List, George, 1979. "Ethnomusicology: A Discipline Defined," dalam Ethnomusicology xxiii (January 1977), 1-5.

Merriam, Alan P. 1964. The Anthropology of Musik. Indiana: Northwestern University Press.

Pfeffer, Georg. 1994. "Musik in Content: Ethno- 
graphy and Meaning" dalam Kuckertz, Josef, 1994, Ethnomusicology in the Context of Other Sciences. Eisenach: Verlag der Musikalienhandlung Karl Dieter Wagner.

Prier, Karl-Edmund. 1996. Ilmu Bentuk Musik. Yogyakarta: Pusat Musik Liturgi

Rasmussen, Ann K. 2001. “The Qur'aan in Indonesian Daily Life: The Public Project of Musikal Oratory" dalam Ethnomusicology Vol 45, No.1 (Winter).

Sedyawati, 1995. "KeIslaman dalam Tari di Indonesia" dalam Jabrohim and S.

Seeger, Anthony. 1995. "Ethnography of musik" dalam Myers, $\mathrm{H}$ (ed). Ethnomusicology: $A n$ Introduction. UK: The Macmillan Press, 88109.
Stein, Leon.1961. Structure and Style; The Study and Analysis of Musical Forms. USA: SummyBirchard Music.

Supanggah, R. (ed.) 1995. Seri Bacaan Etnomusikologi. Surakarta: Masyarakat Seni Pertunjukan Indonesia.

Suprapto, Bibit, 1987. Nadhatul Ulama: Eksistensi Peran dan Prospeknya; Fakta dan Analisa tentang Kebidupan NU. Malang: LP Ma'arif Cabang Malang.

Titon, Jeff Todd. 2003. "Textual Analysis or Thick Description?" dalam Clayton et al. (ed.) The cultural Study of Musik a Critical Introduction. New York dan London: Routledge,171-180. 